\title{
DOI: 10.7596/taksad.v6i4.1054
}

Citation: Oral, M., \& Özdemir, Ü. (2017). Küresel Enerji Jeopolitiğinde Türkiye : Fırsatlar ve Riskler. Journal of History Culture and Art Research, 6(4), 948-959.

\section{Küresel Enerji Jeopolitiğinde Türkiye ${ }^{1}$ : Fırsatlar ve Riskler ${ }^{2}$}

\section{The Position of Turkey in Global Energy Geopolitics: Opportunities and Risks}

\author{
Muhammed Oral ${ }^{3}$, Ünal Özdemir ${ }^{4}$
}

\begin{abstract}
Turkey has various social, economic, cultural and geostrategic advantages and opportunities thanks to its location. However, it is also located between the Middle East, Balkans, and Caucasus, which are among the most depraved and unstable places in the world. This brings geopolitical risks to Turkey.

With respect to energy geography, Turkey draws attention both as a center and as a natural route country that connects supply and demand territories. More than $70 \%$ of the world's oil and natural gas reserves and about $30 \%$ of global consumption currently take place in Europe. Accordingly, Turkey is a terminal country with its energy demand security for resource territories and with its energy supply security for supply territories.

The purpose of this study is to discuss the roles of Turkey with its strategic location in the energy geopolitics centered on oil and natural gas. The study uses the data provided by organizations that engage in significant international and national activities in the industry such as the International Energy Agency (IEA), U.S. Energy Information Administration (EIA), British Petroleum (BP), World Energy Council (WEC), and the Republic of Turkey Ministry of Energy and Natural Resources. Thus, this study uses a quantitative research method through the collection and analysis of secondary data.
\end{abstract}

Keywords: Energy geography, Energy geopolitics, Route country, Turkey, Pipelines.

\footnotetext{
${ }^{1}$ Dünya enerji ekonomisi içerisinde kayda değer bir ağırlı̆̆ı bulunan kaynak ve arz coğrafyalarında ortaya çıkan durumlar (siyasi, ekonomik) küresel enerji piyasasını ve jeopolitiğini etkileyebilmektedir. Bu bağlamda Türkiye, küresel enerji yapısı içerisinde oldukça önemli/bağlayıcı bir ülkedir.

${ }^{2} \mathrm{Bu}$ çalışmanın ortaya çıkarılmasında, Karabük Üniversitesi Sosyal Bilimler Enstitüsünce kabul edilip onaylanan "Enerji Coğrafyası Perspektifinde Türkiye'nin Enerji Politikaları" başlıklı doktora tezinden faydalanılmıştır. Ancak çalışma, söz konusu tezin bir özeti niteliğinde değildir.

${ }^{3}$ Karabük Üniversitesi, Edebiyat Fakültesi, Coğrafya Bölümü, Turkey. E-mail: muhammedoral@karabuk.edu.tr

${ }^{4}$ Karabük Üniversitesi, Edebiyat Fakültesi, Coğrafya Bölümü, Turkey E-mail: uozdemir@karabuk.edu.tr
} 


\section{Öz}

Türkiye konum itibariyle sosyal, ekonomik, kültürel ve jeostratejik açıdan çeşitli avantajlara/firsatlara sahiptir. Ancak söz konusu coğrafya, aynı zamanda dünyanın en buhranlı, istikrarsız mekânlarından olan Orta Doğu, Balkanlar ve Kafkaslar bölgesinde yer almaktadır. Bu durum Türkiye için jeopolitik riskleri de beraberinde getirmektedir.

Enerji Coğrafyası özelinde ise Türkiye, bir merkez ve arz-talep coğrafyalarını birleştiren doğal bir güzergâh ülkesi olarak dikkat çekmektedir. Mevcut durum itibariyle dünya petrol ve doğal gaz rezervlerinin \%70’ten fazlası ve küresel tüketimin yaklaşık \%30’u Avrupa tüketim coğrafyasında gerçekleşmektedir. Buna göre Türkiye, kaynak coğrafyaları için enerji talep güvenliği, arz coğrafyaları için de enerji arz güvenliği yönüyle terminal bir ülkedir.

$\mathrm{Bu}$ çalışmanın amacı, stratejik bir noktada konumlanan Türkiye'nin petrol ve doğal gaz eksenli oluşan enerji jeopolitiğinde ne gibi rollere sahip olduğunu tartışmaktır. Araştırmada; IEA, EIA, BP, WEC, ETKB gibi sektörde uluslararası ve ulusal ölçekte önemli çalışmalar yürüten kuruluşların verilerinden yararlanılmıştır. Dolayısıyla araştırmada ikincil verilerin elde edilmesi ve değerlendirilmesi çerçevesinde nicel metot uygulanmıştır.

Anahtar Kelimeler: Enerji coğrafyas1, Enerji jeopolitiği, Güzergâh ülke, Türkiye, Boru hatları.

\section{GIRIŞ}

Tüm dünyada herhangi bir ülke ya da toprak parçası tarihsel dönemler göz önüne alındığında sosyal ve ekonomik çekicilikleri barındıran refah bölgesi çerçevesinde kendisini stratejik kılan fırsatlara sahip olabilir. Bunlar; uygun iklim koşulları, su kaynakları, verimli tarım arazileri, kara ve deniz ulaşımında önemli ticaret yolları üzerinde bulunması, stratejik enerji kaynaklarında arz coğrafyası olması veya bu kaynakların transferinde geçiş ya da terminal rolde olmasını sayabiliriz.

Bu kapsamda enerji coğrafyaları (üretim-transfer-tüketim bölgeleri) 20. yüzyılın başından beri paylaşım ve güç mücadelelerinin odağında yer almıştır. 1973 ve 1979 petrol krizleriyle yaşanan enerji güvenliği kaygıları sonrasında üretilen politikalar uluslararası ilişkilerde belirleyici (bir güç ya da uluslararası ilişkilerde manevra kabiliyetini daraltan bir durum) unsur olmuştur. $\mathrm{Bu}$ döneme kadar enerjiyi (petrolü) tükenmez bir kaynak gibi gören batı dünyası enerji krizlerine karşı bir taraftan nükleer ve yenilenebilir kaynakları devreye alma, bir taraftan da Orta Doğu'ya yönelik askeri gücü de içine alan katı bir politika sürecine girmiştir. 
1990’lı yıllarda Hazar, 2000’li yıllarla birlikte Doğu Akdeniz bölgeleri enerji eksenli güç mücadelelerinde yer almaya başlamışlardır. Ayrıca petrol ve doğal gazın, körfezler, kanallar, boğazlar gibi yüklenme ve geçiş yolları da jeopolitik açıdan önem kazanmıştır. Bu yüzden enerjiye erişim ve nakil, coğrafyaları stratejik bölgeler haline getirmekte ve buraları jeopolitik denge aracı kılmaktadır. İşte bu yüzden enerjinin jeopolitiği, küresel siyasi ve ekonomik denklemleri dizayn eden güçlü bir aktördür.

Küresel enerji jeopolitiğinde Türkiye ise arz ve talep coğrafyaları arasında doğal bir güzergâh olarak zincirin tamamlayıcı halkası rolündedir. Ayrıca Türkiye, kendisi önemli petrol ve doğal gaz tüketici olması çerçevesinde kaynak ülkeleri için de büyük bir pazardır. Ancak güçlü bir coğrafi konumda yer almak, Türkiye'nin hedeflediği enerji hubu olmasını sağlayacak yeterli bir unsur da değildir. Türkiye'nin sahip olduğu fiziki niteliklerin beşeri firsatlarla (aktif nüfusu, askeri gücü, büyüyen ekonomisi gibi) bütünleştirilmesi gerekmektedir.

\section{Türkiye'nin Sahip Olduğu Coğrafi Firsatlar}

Türkiye, matematik konum itibariyle insan yaşamı açısından en elverişli iklim sahası kabul edilen 1lıman kuşakta yer alır. Bu sahanın bütünü; kuşkusuz ekonomik faaliyetler ve insan hayatı yönünden aynı ölçüde elverişli değildir. Türkiye'nin ılıman kuşak güney yarısında bir konumda bulunması ve de orografik özellikler ile yükselti farklıklarının iklim özelliklerini büyük ölçüde etkilemesi, tarımsal üretim ve toprağa bağlı diğer ekonomik faaliyetlerin geniş ölçüde çeşitlenmesini sağlamıştır. Ülke genelinde doğal çevreden kaynaklanan bu farklılık, beşeri ve ekonomik faaliyetlerin temelini de etkilemiştir (Doğanay, 2014:48). Özel konum bakımından ise Türkiye, eski dünyanın (Asya-Avrupa-Afrika) kesişim noktasına karşılık gelmekte ayrıca üç tarafı denizlerle çevrili olduğu için deniz ulaşımında da stratejik bir konumdadır. Çünkü İstanbul ve Çanakkale boğazları Karadeniz'e komşu ülkelerin açık denizlere ulaşabileceği tek güzergâhtır. Akdeniz, Karadeniz ve Ege Denizi Cebelitarık ve Süveyş Kanalı ile de sırasıyla Atlas ve Hint Okyanusuna bağlanmaktadır. Belirtilen bu matematik ve özel konum nitelikleri nedeniyle tarih boyunca Anadolu, her zaman çok değerli bir toprak parçası olmuştur.

Türkiye’nin lokasyonu tarih boyunca dünya devletlerinin ilgi odağında yer almış ve daima sahip olunmak istenmiştir. Türkiye'nin coğrafi konumu; Balkanlar, Kafkaslar ve Orta Doğu'nun birleştiricisi ve ayırıcısıdır. Bu coğrafi konum dünyada ve bölgede oluşabilecek her türlü güç yapısına göre stratejik bir önem taşır (İlhan, 1999:208). (Harita 1.). 


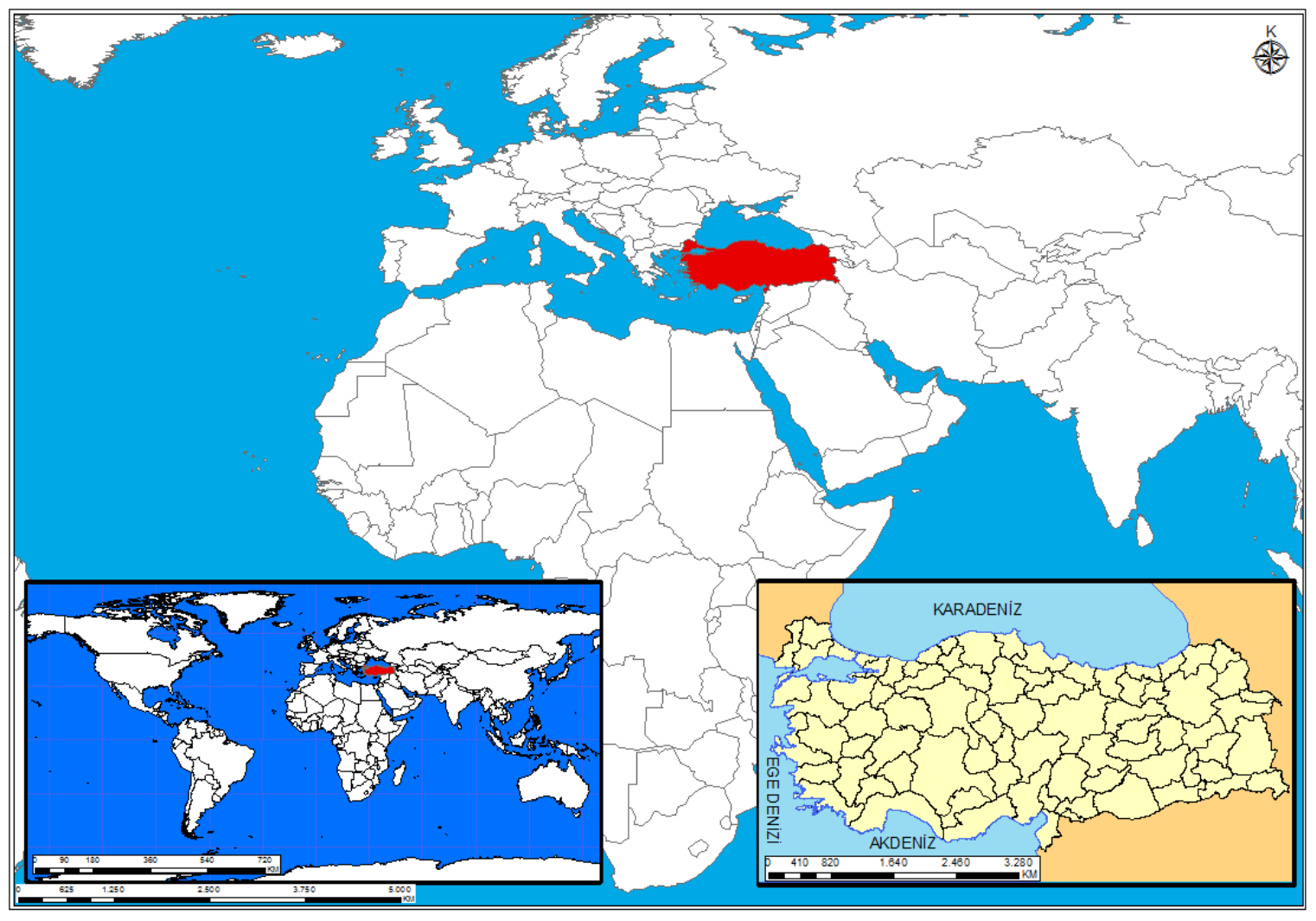

Harita 1. Türkiye’nin Lokasyonu. Kaynak: Oral, 2017:185

Tarih boyunca her zaman bir mücadele alanı olan Anadolu aynı zamanda pek çok medeniyetin ortaya çıkmasına da imkân tanımıştır. Doğu ve batı dünyası arasında yalnızca bir sınır hattı değil aynı zamanda farklı kültürlerin karşılaştığı, ender görülen bir jeokültür sahasıdır. Bölgenin, hâkimiyet sağlayan konumu, Hititlerden Türkiye Cumhuriyeti’ne uzanan çeşitli devletlerin kuruluşu ile uluslararası ilişkiler ve politikalarda söz konusu coğrafyanın siyasal gücünü kuvvetlendirmiştir.

Türkiye'nin sahip olduğu coğrafyayı önemli kılan bu etmenler imparatorluktan kalma stratejik bir güç yaratmaktadır. Osmanlı, 20. yüzyılın başına kadar küresel siyasete yön verebilen aktörlerden biri olarak büyük bir imparatorluktu. Bu durumun hala önemli jeopolitik sonuçları bulunmaktadır (Lacoste, 2008:227). Brzezinski ise Türkiye'nin mevcut jeopolitik önemine vurgu yaparak Hazar Havzası ve Orta Asya'nın geleceği ile ilgili görüşmelerin Türkiye ve ABD arasındaki stratejik yakınlaşmaları arttırabileceği üzerinde durmuştur. Bunun yanında Türkiye'nin Avrupa'dan dışlanmaması gerektiği, aksi halde, NATO’nun genişlemesinin engelleneceği ve Orta Asya'nın dünya ile bütünleşmesi ve bölgede istikrarın sağlanmasında Avrupa'nın sınırlı bir etkisinin olacağını da belirtmiştir. Çünkü nüfus gücü, askeri gücü, büyüyen ekonomisi, artan eğitim düzeyi gibi beşeri coğrafya nitelikleri Türkiye'nin jeopolitik 
gücünü arttırmakta ve bu durum Türkiye'ye bölgesel bir güç olarak öne çıkma firsatı tanımaktadır.

Bununla birlikte Çin'in öncülük ettiği tarihi ipek yolunun yeniden canlandırılması ve ABD’nin dünya ekonomisindeki liderliğini kırmayı amaçlayan (Yeni İpek Yolu Projesi) Avrupa ve Asya'da 60 ülkeyi ticaret ve ulaşım olarak birbirine bağlamayı (hızlı tren güzergâhları, boru hatları, hava alanları, elektrik bağlantısı gibi) öngörmektedir. Dolayısıyla bu projede de Türkiye coğrafi avantajların sağladığı hayati bir role sahiptir.

\section{Türkiye’nin Karşılaştığı Jeopolitik Riskler}

Türkiye Cumhuriyeti, dünyanın merkez coğrafyasını elinde tutmuş olan Selçuklu ve Osmanlı imparatorluklarındaki Türk hegemonyası bakiyesinde bir orta alan devleti olarak, geçmişten günümüze merkezi coğrafyaya yönelen bütün bölgeselleşme plan ve projelerinin birinci derecede hedefi konumunda olmuştur (Çeçen, 2015:326). Belirtildiği üzere Türkiye'nin sahip olduğu coğrafi konum, dünya üzerinde önemli firsatlara sahip olsa da ABD, Rusya, Almanya, İngiltere, Fransa, Çin gibi büyük aktörlerin mücadele pergelinde yer aldığ için bunun bir de olumsuz yansımaları bulunmaktadır. Öyle ki Türkiye, 20. yüzyılın başlarından beri petrol eksenli mücadele alanı haline gelen ve bir türlü siyasi istikrara kavuşturulmayan Orta Doğu'ya, 1990'larla birlikte küresel enerji piyasasında oldukça önem kazanan Hazar enerji bölgesine, Doğu Akdeniz enerji sahasına ve Afrika'ya kayıtsız kalamayacak kadar yakın olması Türkiye coğrafyasını jeopolitik açıdan riskli duruma düşürmektedir. $\mathrm{Bu}$ durum yalnızca jeopolitik açıdan risk getirdiği anlamına gelmez. Aynı zamanda ulusal güvenlik için yapılan savunma yatırımları, enerji arz güvenliğini sağlamada doğan siyasi manevra kabiliyetinin azalması gibi çeşitli problemleri de beraberinde getirmektedir. Böyle bir süreç elbette yüksek sosyal ekonomik koşulların getirdiği refah ortamında yapılabilecek imalat üretimini ve teknolojik gelişimi baltalamaktadır. Buna göre, Türkiye'nin gelişmekte olan ülkeler grubundan sıyrılamayışının ve kişi başına düşen milli gelirinin arzulanan düzeyde olmamasının en büyük sebeplerinden biri de jeopolitik açıdan riskli bir bölgede bulunmasıdır.

Türkiye, batılı güçlerin emperyal hedefleri doğrultusunda bölgede güçlü bir devlet teşekkülünde istenmediği için Orta Doğu kaynak coğrafyasında geçtiğimiz yüzyıldan beri çeşitli problemlerle karşı karşıya kalmıştır. Hatta bunların arasında Türkiye’ye ASALA/PKK/DAEŞ gibi terör örgütü faaliyet yansımaları da olmuştur.

Bu bağlamda ortaya şu soru çıkmaktadır, Türkiye'nin bulunduğu coğrafya daha çok firsat mı yoksa risk mi barındırmaktadır? Esasen bu soruya net bir yanıt vermek güçtür. Önemli olan 
Türkiye'nin karşı karşıya kaldığı coğrafya kaynaklı sorunları en rasyonel şekilde özellikle uzun vadeli planlar çerçevesinde çözüme kavuşturabilmektir.

Türkiye yukarıda da belirtildiği üzere esasen dünyanın en merkezi toprak parçalarından birinde yer almaktadır. Ancak büyük güçlerin enerji güvenliği kaygıları doğrultusunda sürdürdüğü siyasi ve ekonomik politikalar Türkiye'yi de bir sorunsalın içine çekmiştir/çekmektedir. Geçmişte ve bugün Türkiye Cumhuriyeti'nin yüz yüze kaldığı siyasi ve ekonomik çöküşlerin arka planında batılı güçlerin olduğu pek çok siyasetçi tarafından da belirtilmesine rağmen politika üretiminde yaşanan olumsuzluklar bu gerçeğin değişmesine engel olmuştur. Türkiye'nin bu süreçte atabileceği en önemli adım eğitim-bilim ve teknolojiye yatırımlar yaparak inovasyon kültürüne erişme yoluyla yenilikleri gerçekleştirebilecek bir iradeye sahip olmak ve bu çerçevede politika üretmek olabilirdi. Ancak bunun yerine gelişmiş dünyanın peşinden gitmek ilk etapta daha ekonomik gelmiş (batılı ülkeler bu firsatı da sunmuşlardır) dolayısıyla süreç içerisinde belki de Türkiye'nin kronik bir ikinci dünya ülkesi olmasına neden olabilecek, üretim değil tüketim eksenli bir ekonomik sistem ortaya çıkmıştır.

\section{Türkiye'nin Enerji Jeopolitiği}

Enerji Coğrafyası açısından da bulunduğu lokasyon itibariyle Türkiye, yalnızca doğu-batı arasında değil, aynı zamanda kuzeyi ve güneyi arasında bünyesinde terminal ve merkez olma potansiyelini bulunduran stratejik bir bölgededir. Öyle ki dünyadaki petrol ve doğal gaz rezervlerinin \%70’i Türkiye'nin yakın coğrafyasında bulunmaktadır. (Harita 2.).



Harita 2. Türkiye'nin Yakın Çevresindeki Petrol ve Doğal Gaz Rezervleri. Kaynak: BP 2016:620 'den yararlanarak yazar tarafindan oluşturulmuştur. 
Tarihi süreç içerisinde insan ihtiyaçlarına kaynak sağlayan nesnelerin bulunduğu sahalar güç mücadelelerinin merkezinde yer almıştır. Günümüzde de güçlü olmak isteyen devletler enerji kaynaklarının bulunduğu bölgeleri ve ulaşım yollarını kontrol etme çabasındadırlar. Türkiye'yi çevreleyen Hazar ve Orta Doğu bölgelerinde zengin petrol ve doğal gaz yatakları bulunmaktadır. Bu durum Türkiye'ye enerji kaynaklarının iletiminde bir terminal olma firsatı sunmaktadır (Harunoğulları, 2013:127).

Dünya enerji üretim ve tüketimi hızla artan dünya nüfusu, giderek yükselen sanayileşme ve şehirleşme oranları gibi değişkenler bu üretim ve tüketimi artırmış bir taraftan da teknolojiyle beraber geliştirmiştir (Doğanay ve Coşkun, 2017:6). Buna göre enerji arz, talep ve transit coğrafyalar stratejik bir değer kazanmıştır. Bu bağlamda Türkiye de enerji jeopolitiğinde belirleyici bir niteliktedir. Enerji üretim ve tüketim bölgeleri arasındaki bağlantıyı sağlama adına, EIA’nın '’2017 Türkiye Analizi Raporu’'nda Türkiye'nin; Orta Asya, Rusya ve Orta Doğu'daki petrol ve doğal gazın Avrupa'ya ve diğer Atlantik pazarlarına taşınmasında stratejik öneminin giderek arttığı belirtilmiștir. Ayrıca Türkiye, sahip olduğu istikrar ve askeri güç ile birlikte bölgedeki enerji kaynaklarının ve bu kaynakların arz güvenliğinin sağlanmasında da önemli bir aktördür.

Türkiye, kaynak ve arz bölgeleri yani enerji kaynakları üretim ve tüketim coğrafyaları arasında, bir enerji ağında konumlanmıştır. Bu özellik Türkiye’ye transit rolünün ötesinde enerji dağıtım merkezi/kavşağı (hub) olabilme avantajı sağlamaktadır. Petrol ve doğal gazın Avrupa'ya güvenli ve istikrarlı olarak ulaştırılması, kaynak coğrafyasındaki (Azerbaycan, Türkmenistan, Kazakistan, Doğu Akdeniz gibi bölgelerde) zengin rezervlerin küresel enerji ticaretinde çok daha etkin bir rol üstlenmesi, Türkiye'nin içinde bulunduğu projelerle gerçekleşebilecektir. Bu yüzden bölgede enerji yatırımlarında/yatırım planlarında Türkiye mutlak surette politikaların içinde bulunmaktadır. Ayrıca Türkiye'nin kendisi de petrolde \%93, doğal gazda \%99 bağımlılık oranlarına sahip olması noktasında büyük bir enerji pazarıdır. Bu anlamda Türkiye'nin enerji politikalarındaki temel unsurları petrol ve doğal gazda kaynak ülke çeşitliliği, yenilenebilir kaynakların elektrik üretimindeki payının arttırılması, nükleer gücün enerji portföyüne dahil edilmesi ve uluslararası boyutta ise coğrafi konumunun sunduğu avantajları kullanarak bir enerji hubu olabilmektir. Türkiye Coğrafyası, sorunların çözümü ile bölgede enerji ve siyaset alanlarında istikrarın sağlanması bağlamında kritik bir role sahiptir. Bu bağlamda enerji sorununu anlamadan dünya siyasal konjonktürünü anlamaya çalışmak pek olası görünmemektedir (Yarman, 2012:79).

Enerji jeopolitiği bağlamında Türkiye açısından en önemli hedef, küresel bir enerji ticaret merkezi/kavşağı (hubu) olabilmektir. Türkiye; kaynak coğrafyasında yer alan ülkeler ve arz coğrafyasında yer alan Avrupa gibi tüketim bölgeleri arasında bağlantıyı kurabilecek en 
rasyonel güzergâh Türkiye'nin de içinde yer aldığı enerji projeleridir. Buna göre Türkiye'nin petrolde Samsun (Ünye) Ham Petrol Boru Hattı Projesi bulunurken doğal gazda Trans Anadolu Doğal Gaz Boru Hattı (TANAP) Projesi, Trans Hazar Doğal Gaz Boru Hattı Projesi, Trans Adriyatik Doğal Gaz Boru Hattı Projesi (TAP), Türkiye-Yunanistan-İtalya Doğal Gaz Boru Hattı Projesi (ITGI/ITG), Türk Akımı Doğal Gaz Boru Hattı Projesi, Mavi Akım II Doğal Gaz Boru Hattı Projesi, Irak-Türkiye Doğal Gaz Boru Hattı Projesi, Katar-Irak-Türkiye Doğal Gaz Boru Hattı Projesi, Misır-Türkiye (Arap) Doğal gaz Boru Hattı Projesi gibi projeler bulunmaktadır. Bu projelerden bazıları dönemsel konjonktür gereği öne çıkabilirken bazıları ekonomik olmayan proje şeklinde görülebilmektedir. Belirtilen unsurlar çerçevesinde Türkiye'nin içinde bulunduğu projelerin hayata geçmesi Türkiye'nin bölgesel ve küresel düzlemde etkinliğini arttıracaktır. (Harita 3.).

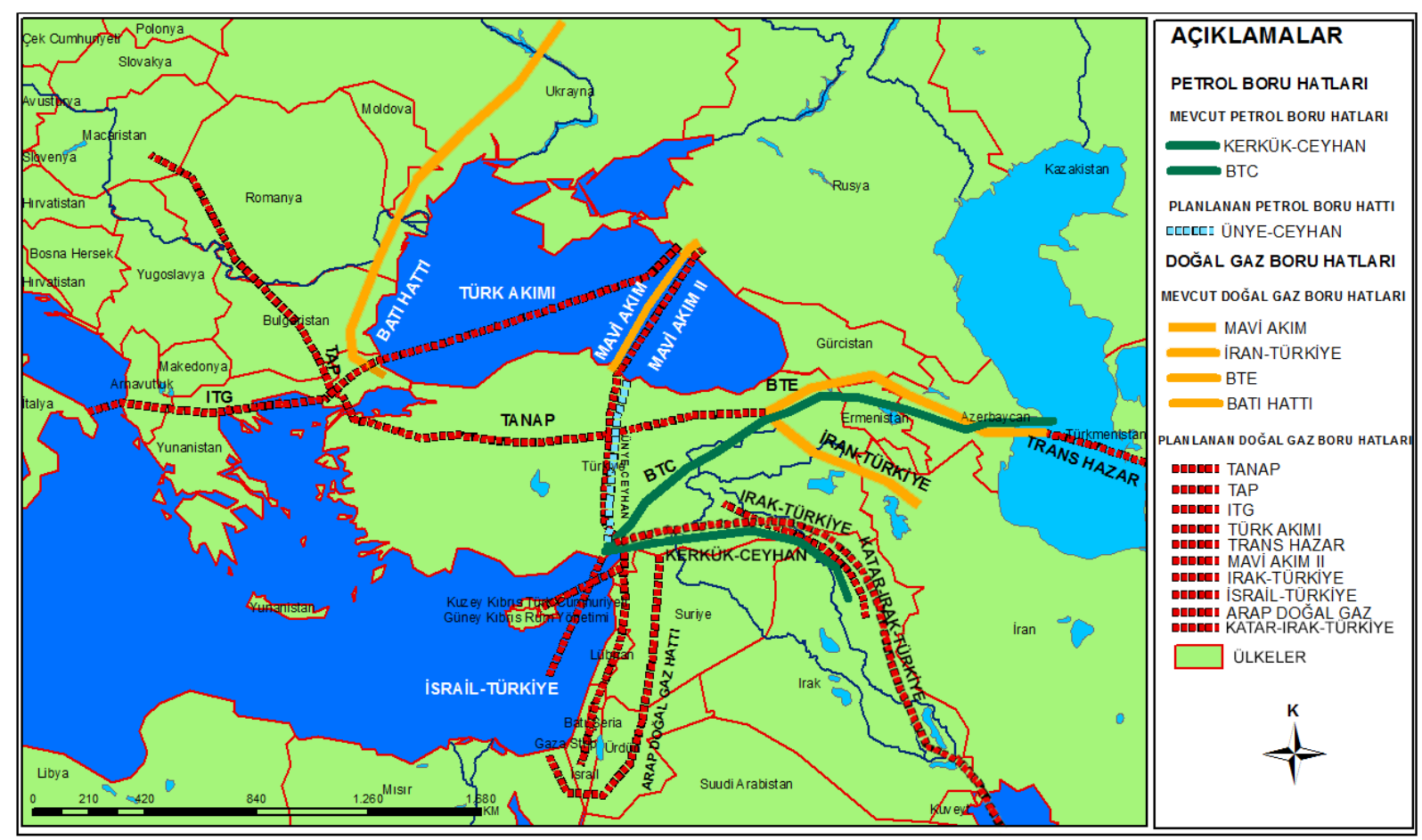

Harita 3. Türkiye’nin Mevcut ve Planlanan Petrol ile Doğal Gaz Boru Hatları. Kaynak: Yazar

Boru hatlarıyla ilgili mevcut ve planlanan hatlar incelendiğinde, Türkiye'nin bölge arz ve talep güvenliği açısından stratejik önemi görülmektedir. Mevcut olan BTC ve Irak-Türkiye Ham Petrol Boru Hattına ek olarak Samsun-Ceyhan Ham Petrol Boru Hattı planlanmaktadır. Bu durum elbette Ceyhan'in bir terminal olarak küresel piyasada daha da etkin hale gelmesine imkân tanıyacaktır. 
Doğal gazda ise Rusya-Türkiye (Mavi Akım, Batı Hattı), İran-Türkiye hatlarına ek olarak TANAP (devam ediyor-\%72'si tamamlandı), TAP, Trans-Hazar, Türk Akımı, Irak-Türkiye, Katar-Irak-Türkiye, Mısır-Türkiye, Doğu Akdeniz kaynaklarının nakli için İsrail-Türkiye gibi hatlar planlanmaktadır. Söz konusu kaynak bölgelerindeki petrol ve doğal gaz nakli için Türkiye en uygun güzergâhtır. Rezerv miktarları incelendiğinde, Rusya ile birlikte Hazar enerji sahası yüksek oranda petrol ve doğal gaz rezervlerine sahiptir. Bununla birlikte Irak ve İran'daki petrol ve doğal gaz miktarları da bu kaynakların pazara, dolayısıyla nakle ihtiyaç duyduğunu göstermektedir. $\mathrm{Bu}$ yüzden bu bölgelerdeki kaynakların tüketici pazarlarına ulaştırılmasında Türkiye en önemli aktördür.

Şüphesiz Rusya'dan gelecek petrol ya da doğal gazın naklinde Karadeniz ${ }^{5}$ de büyük rol üstlenmektedir. Hedeflenen projelerde Karadeniz stratejik bir geçiş sahasıdır. Karadeniz havzasının enerji jeopolitiği açısından önemi, muhtemel petrol ve doğal gaz rezervlerinin yanında bu kaynakların doğudan batıya (Rus-Avrupa için) ve kuzeyden güneye (RusyaTürkiye için) transferidir.

$\mathrm{Bu}$ durumun jeopolitik yansıması neticesinde, Karadeniz enerji transfer güzergahında ön plana çıkmış, enerji güvenliğini hayati gören uluslararası aktörlerin Karadeniz politikalarını şekillendirmiştir (Erbaş, 2012:77-78).

Doğu Akdeniz'in ise özellikle doğal gazının Avrupa tüketim coğrafyasına ulaştırılması için de Türkiye en uygun ve en güvenli yoldur. Ancak bölgede özellikle Türkiye ve Güney Kıbrıs Rum Kesimi arasında paylaşım (deniz yetki alanları) sorunları bulunmaktadır. Kıbrıs, Türkiye açısından sadece Doğu Akdeniz'in değil aynı zamanda Ege'nin ve Karadeniz'in de anahtarı durumundadır. Kıbrıs konusunda Türkiye'nin etkisini azaltacak ya da tamamen ortadan kaldıracak herhangi bir çözüm, Türkiye'yi yalnızca Doğu Akdeniz'den değil tüm Akdeniz'den tecrit edecektir. Akdeniz, Afrika enerji kaynaklarının Avrupa'ya açılan terminali olmasının yanında Süveyş ve Türk boğazları bağlantısı nedeniyle Karadeniz de dahil olmak üzere bir kontrol sahasıdır (Tarakçı, 2014:104-160). Buna göre Akdeniz'in ve bir enerji sahası olarak Doğu Akdeniz'in Türkiye'nin uluslararası konjonktürde etkin rolünü sürdürmesi açısından önemi büyüktür.

\section{Sonuç ve Öneriler}

Tarihi dönemler itibariyle her daim elde edilmesi gereken bir toprak parçası olarak görülen Anadolu, bölge siyasetinde belirleyici bir mekân olmuştur. Ticaret, ulaşım, enerji gibi sektörlerde merkezi bir rol üstlenen coğrafya aynı zamanda Orta Doğu'daki siyasi ve

\footnotetext{
${ }^{5}$ Ayrıca, Karadeniz dip suları Türkiye’nin 100-180 yıllık enerji talebini karşılayabilecek hidrojen potansiyeline sahiptir.
} 
ekonomik istikrarsılıklardan da etkilenmektedir. Esasen Orta Doğu'daki bu durum -ki bu politikalar içinde bir Kürt devleti kurulması da hedeflerden biridir- bölgeyi ''kolay lokma', yapma hedeflerinin bir yansımasıdır. Batılı devletler için bölgeyi kontrol altında tutmak makyevelist bir hedefi teşkil etmektedir. Ayrıca 2000 yılından beri Putin'in iktidara gelmesinden sonra, petrol ve doğal gazı siyasal bir güç/silah olarak kullanan Rusya da bölgede etkin bir rol üstlenmek istemekte ve bu coğrafyayı tamamen ABD kontrolüne birakmak istememektedir.

Bu yüzden, Türkiye'nin yakın coğrafyasında yer alan (bazı kaynaklarda Türkiye'nin de içinde bulunduğu) Orta Doğu, petrol eksenli güç mücadelelerinin odağında 20. yüzyılın başından beri küresel siyasette sorunların en fazla ve en belirgin olduğu saha olmuştur (son olarak Suriye'den Türkiye'ye 3 milyon dolayında mülteci hareketi gerçekleşmiştir). Özellikle ABD, İngiltere, Almanya, Fransa gibi devletler tarafından enerji güvenliği kaygıları doğrultusunda yürütülen politikalar bölgeyi sürekli bir çekişmenin ve siyasi sorunların merkezinde tutmuştur. Çünkü bir bölge ancak istikrarsılılı unsuru olduğunda askeri müdahaleye uygun hale gelecektir.

Avrupa tüketim bölgesi açısından enerjiye erişim Türkiye'nin içinde bulunduğu projelerle en rasyonel şekilde gerçekleşebilecektir. Kaynak coğrafyasında bulunan ülkeler için de enerji ihracatı en makul ve güvenli şekilde Türkiye üzerinden mümkündür. Türkiye'nin güçlü coğrafi (jeopolitik konum, nüfus, ekonomi), askeri ve tarihi imajı bu güveni vermektedir. Aynı zamanda bir ihracat ve ithalat köprüsü olarak Türkiye'nin kendisi de büyük bir pazardır. Buna göre Türkiye, tarihsel süreçte olduğu gibi çatışmacı değil iş birliğine dayalı paylaşımcı bir ortaktır.

Türkiye'nin bir enerji hubu olmasıyla ilgili en büyük firsatı, kaynak ve arz coğrafyaları arasında doğal ve en rasyonel güzergâh olmasıdır. Küresel bağlamda bulunulan coğrafya önemlidir ancak doğrudan doğruya enerjide belirlenen hedeflere ulaşılmasında tek başına yeterli değildir. Çünkü enerji piyasası tek boyutlu (yalnızca üretim ve tüketime dayalı) bir sektör değil, içerisine siyasi ve ekonomik değişkenleri, güç mücadelelerini de alan kompleks ilişkiler bütünüdür. Enerji piyasası küresel bir piyasadır ve küresel siyasi oyunların sürekli tekrarlandığ1 dahası yenilenebildiği bir araç olarak içerisinde ikinci ve üçüncü ülkelerle birlikte uzlaşıyı da gerektirmektedir. Bu süreçlerin ortaya çıkabilmesi için ise üç bölgede de (kaynak-geçiş/terminal-arz coğrafyaları) siyasi ve ekonomik istikrarın varlığı kaçınılmazdır. Sektöre olan yatırımlar ile bu yatırımların artış göstermesi de enerji hubu olmanın gerekliliğidir. Gazprom, Rosneft, BP, Saudi Aramco gibi sektör piyasasında ekonomik olarak güçlü yer edinmiş lider şirketler olursa diğer unsurlarla birlikte bir piyasa oluşturulması mümkün olabilir. 'Bu şirketler söz konusu ülkenin petrol, doğal gazıyla ekonomik bir güç elde etmişlerdir, Türkiye'nin ise böyle bir durumu yoktur'" yaklaşımı olsa bile yatırımlar boyutunda yani upstream ve downstream yatırımlarını tek elden yürütebilecek milli bir şirket önemli bir piyasa gücü yaratabilir. Dolayısıyla bir enerji ticaret merkezi olabilmek için birkaç unsurun varlığından bahsedilebilir (Şekil 1.). 
Şekil 1. Enerji Ticaret Merkezi Olabilmenin Unsurları

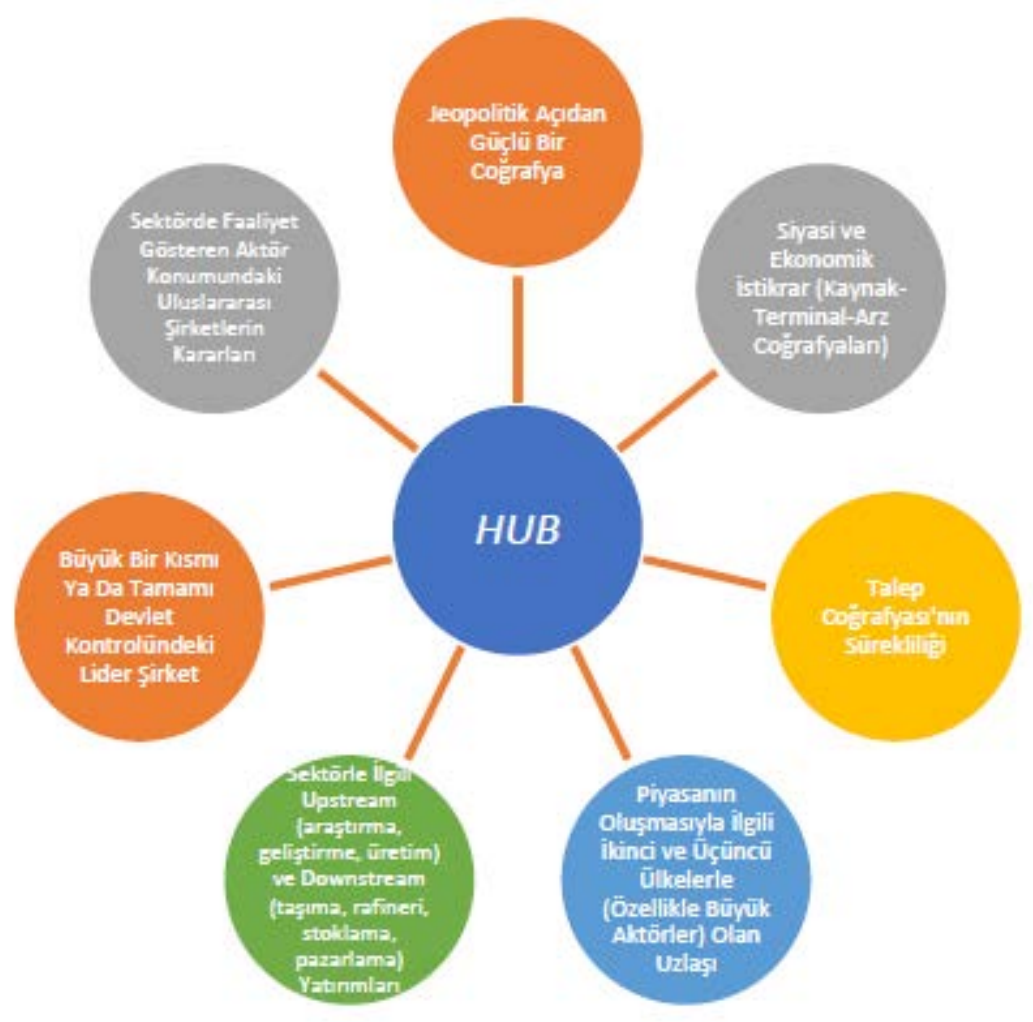

Kaynak: Oral, 2017:412

Türkiye, coğrafyasının stratejik niteliğini, siyasi ve ekonomik güçle bütünleştirmeli -ki böylece Orta Doğu ve Doğu Akdeniz'deki sorunların çözümünde daha etkin olunacaktır- tüm sektörlerde olduğu gibi enerji sektöründe (özellikle yenilenebilir kaynaklar) de kendi teknolojisini geliştirmelidir. Türkiye için esas olan teknolojinin transferi değil (teknoloji transferi 1970-1980'li yıllara ait olan bir teknolojik davranış biçimidir) teknolojinin üretilmesidir. Türkiye'nin bilgiyi üreten ülke olması küresel siyasette aktör olma hedefi taşıyan bir ülke için kaçınılmazdır. Bugün Türkiye'nin 3 trilyon dolar GSMH'ye sahip olduğu varsayıldığında jeopolitik niteliğini çok daha güçlü kullanabileceği ortadadır. Buna göre Türkiye'nin önünde iki politika ayağı bulunmaktadır. Birincisi, gelişmiş dünyanın her alanda sahip olduğu bilgi ve teknolojiye erişme hedefi doğrultusunda politikalar üretmek, ikincisi ise gelişmiş dünyanın hedeflediği bilgi ve teknolojiyi daha önce elde edebilmek için politika ve uygulamalar üretmektir. Her sektörde büyük çaplı kurumsal firmalardan KOBI'lere, bağımsız girişimcilere kadar teşvikler ve destekler verilmelidir. Bu bağlamda ayrı bir kurumsal yapı olarak İnovasyon (Yenilikçilik) Bakanlığ ${ }^{6}{ }^{6}$ oluşturulabilir.

\footnotetext{
${ }^{6}$ Diğer bakanlıklardan farklı bir yapıya ve bütçeye sahip olmalı. Her ilde bilim komisyonu bulunan bir temsilciliği bulunmalı. Orta okul öğrencisinden üniversitedeki akademisyene kadar her sınıftan vatandaş, bulduğu bir yeniliği, icadı uzun uzadıya prosedürler olmaksızın bu kurula sunabilmeli ve vatandaşa altı ay içinde dönüt verilmeli. Onaylanan buluş için devlet ilgili bakanlık eliyle ya doğrudan yatırım yapmalı ya da yatırımcı bulmalıdır. Bunun için ayrıca söz konusu bakanlık bünyesinde bir birime yer verilmelidir.
} 


\section{Kaynakça / References}

Aydın, L.; Bolat, İ. \& Yavuz, M. (2014) Uluslararası Enerji Siyasetinin Dinamikleri ve Türkiye'ye Yansımaları, Ankara Strateji Enstitüsü Yayını, Ankara.

Boru Hatları İle Petrol Taşıma Anonim Şirketi (BOTAŞ) (2011) Uluslararası Projelerimiz, BOTAŞ Yayını, Ankara.

British Petroleum (BP) (2016) Statistical Review of World Energy, BP Publication, London, United Kingdom.

British Petroleum (BP) (2017) Statistical Review of World Energy, BP Publication, London, United Kingdom.

Brzezinski, Z. (1997) Büyük Satranç Tahtası, (çev. Y. Türedi), İnkılap Yayınevi, İstanbul.

Çeçen, A. (2015) Türkiye’nin Konumu, İleri Yayınları, İstanbul.

Doğanay, H. (2014) Türkiye Beşeri Coğrafyası, Pegem Akdemi Yayıncılık, Ankara.

Doğanay, H. \& Coşkun, O. (2017) Enerji Kaynakları, Pegem Akademi Yayıncılık, Ankara.

Erbaş, G. (2012) Klasikten Eleştirel Jeopolitiğe Karadeniz Jeopolitiğinin Dönüşümü, Doktora Tezi, Ankara Üniversitesi, Sosyal Bilimler Enstitüsü, Ankara.

Harunoğulları, M. (2013) Yumurtalık-Ceyhan Enerji Yatırımları ve Çevresel Etkileri, Doktora Tezi, Atatürk Üniversitesi, Sosyal Bilimler Enstitüsü, Erzurum.

İlhan, S. (1999) Dünya Yeniden Kuruluyor, Ötüken Yayıncılık, İstanbul.

Lacoste, Y. (2008) Büyük Oyunu Anlamak, (çev. İ. Akça), Nergis Televizyonu (NTV) Yayını, İstanbul.

Mammadov, A. (2013) 'Azerbaycan Dış Politikasında Enerji Faktörü’, Akademik Bakış, Sayı: 35, s.1-15.

Oral, M. (2017) Enerji Coğrafyası Perspektifinde Türkiye’nin Enerji Politikaları, Doktora Tezi, Karabük Üniversitesi, Sosyal Bilimler Enstitüsü, Karabük.

Tarakçı, N. (2014) Türkiye Merkezli Jeopolitik Analizler, Türk Asya Stratejik Araştırmalar Merkezi (TASAM) Yayınları, İstanbul.

Trans Adriyatik Doğal Gaz Boru Hattı (TANAP) (2015) ''TANAP Nedir?', http:// www.tanap.com/tanap-projesi/tanap-nedir/, Erişim Tarihi: 07.07.2017.

Türkiye Petrolleri (TP) (2016) Ham Petrol ve Doğal Gaz Sektör Raporu, TP Yayını, Ankara.

U.S. Energy Information Administration (EIA) (2017) Country Analysis Brief: Turkey, EIA Publication, Washington D.C., USA.

Yarman, T. (2012) Enerji Kaynakları, Okan Üniversitesi Yayını, İstanbul. 